\title{
Utilization and recycling of municipal solid waste in a subarctic zone
}

\author{
Elena V. Savenkova ${ }^{1, *}$, Marderos Ara Sayegh ${ }^{2}$, Alexandr Y. Bystryakov ${ }^{1}$, \\ Tatiana K. Blokhina ${ }^{1}$, and Oksana A. Karpenko ${ }^{1}$ \\ ${ }^{1}$ Economics department. Peoples Friendship University of Russia (RUDN University) \\ 6, Miklukho-Maklaya st., Moscow, 117198, Russian Federation. \\ ${ }^{2}$ Wroclaw University of Science and technology, Faculty of Environmental Engineering, \\ ul. Norwida 4/6, 50-373 Wroclaw, Poland
}

\begin{abstract}
Municipal solid waste (MSW) collection and disposal is one of the major problems of urban environment in most countries worldwide today. The problem of utilization of solid waste in the Northern Europe on the Kola Peninsula was raised in this article, where the ground arrangement in a subarctic zone is very special and the weather conditions are severe. The paper main goal is to verify long-term impact of the Mezhdurechie municipal landfill on the atmosphere in Kola Peninsula. The paper also aims to establish the holding actions for recycling and utilization of worn-out tires for mentioned municipal landfill. The ground concentrations of pollutants from the operational sources were presented. The proposed recycling development in this paper has a positive impact on the ecoindustry and ensures environmental safety and municipal economy.
\end{abstract}

\section{Introduction}

Solid waste landfills remain the most widespread way of waste disposal. Annually many hectares of the earth are alienated for solid waste landfills, big areas are already occupied by unauthorized dumps [1]. Nowadays development and construction of modern high-eco-friendly solid waste landfills is one of the main objectives of environmental policy of the state. There is also an important problem of processing of waste including processing of the used tires, these materials could be reused, recycled, or converted to energy to displace the use of virgin materials.

Landfills are now a hot topic which need to minimize their environmental and social impacts [2, 3]. Municipal solid waste (MSW) collection and disposal is one of the major problems of urban environment in most countries today. The modern available technologies and solutions in this area should be implemented $[4,5]$.

Several years ago a solid waste landfill in Kola Peninsula in Murmansk region of Russia named Mezhdurechie started to work. It is situated in subarctic climatic zone in Kola Peninsula. The ground arrangement in a subarctic zone is very special and is expressed in

\footnotetext{
* Corresponding author: savenkova.rudn@mail.ru
} 
severe weather conditions: long cold winters, strong winds, cold winter and rare summer warming to $+15^{\circ} \mathrm{C}$. Such weather conditions differ from the Arctic zone by only in a large amount of rainfall, a little more high average annual temperature and smaller quantity of zones of permafrost. In Murmansk region a large number of swamps is connected with plentiful rainfall which cannot evaporate completely under weak solar radiation.

In Murmansk region transportation of $\mathrm{MSW}$ and its neutralization is carried out by specialized motor transport of the enterprises serving the system of rubbish disposal. The recycling industry doesn't exist in Murmansk region. Nevertheless, there are numerous landfills of MSW and also there are a lot of worn-out automobile tires in other regions.

The main environmental problems in a subarctic zone of Murmansk region are: degradation of soil and land resources; impurity of superficial water resources; air pollution as a result of emissions; reduction of the area of green plantings in water protection to a zone.

In the territory of the region the only enterprise for industrial processing of household waste - JSC Plant of MSW is situated in Murmansk. The main part of household waste of Murmansk, Severomorsk, Kola arrives on thermal neutralization on JSC Plant of MSW. The incineration plant processes only $10 \%$ efficiency from the waste of the Murmansk region [6]. Combustion of MSW is carried out without preliminary sorting. As a result there is a significant amount of harmful substances in the air. In the same time additional pollution is resulted by the burning of worn-out automobile tires nearby. Table 1 presents the data of pollutants emitted to the atmosphere by burning worn-out car tires [7].

Table 1. The data of emitted pollutants to the atmospheric by burning worn-out car tires.

\begin{tabular}{|c|c|c|}
\hline Name of pollutants & The most single emission, [gr/cm] & Threshold limit value, [gr/m ${ }^{3}$ ] \\
\hline $\begin{array}{c}\text { Divanadium pentoxide } \\
\text { (dust) }\end{array}$ & 0.083 & - \\
\hline Dioxide of nitrogen & 8.25 & 0.2 \\
\hline Nitrogen oxide (II) & 1.34 & 0.4 \\
\hline Hydrochloride & 0.06 & 0.2 \\
\hline Dioxide of sulfur & 37.22 & 0.5 \\
\hline Carbon oxides & 0.006 & 5.0 \\
\hline Hydrofluoride & 0.12 & 0.02 \\
\hline
\end{tabular}

The established component structure of worn-out car tires and the chemical composition of rubber in worn-out tiers (acetone extract $-12.4 \%$, ashes $-5.1 \%$, technical carbon $33.3 \%$ and polymers $-49.2 \%$ ) which confirm that the dangerous pollutants are thrown out to the atmospher.

The paper main goal is to verify long-term impact of the municipal landfill of Mezhdurechie on the atmosphere in the Kola Peninsula. The study also aims to establish the holding actions for recycling and utilization of worn-out tires for this municipal landfill.

\section{Materials and methods}

The analysis of air on the landfill was carried out. Calculation of dispersion of impurity in the atmosphere was executed on the unified program of calculation of air pollution "The Ecologist 3.00" for the warm period of year, as a worst period of dispersion of pollutants. The program calculates the maximum ground concentration of pollutants, at the most adverse weather conditions, including dangerous speeds and the directions of the wind. Selection and the analysis of tests of atmospheric air were carried out by the laboratory with 
accreditation in the respective area. There calculations were carried out for dispersion of pollutants in the atmospheric air.

Background concentration were adopted by data Federal state budgetary institution "Murmansk Department of the Public Meteorological Service" which are:

- ground concentration on the settlement platform on a step of $300 \mathrm{~m}$.

- concentration of pollutants were defined at the height of $2 \mathrm{~m}$ (breath level).

The calculation of ground concentration was performed in 7 settlement points as follow: 4 point on ground border $(1000 \mathrm{~m})$, and 1 point on the lands under perspective country construction (at distance about $1.2 \mathrm{~km}$ in east direction from site borders), 1 point on the lands under perspective housing construction (at distance about $3.2 \mathrm{~km}$ in the southeast direction from site borders), 1 point on the border of the next residential development of the Mezhdurechie (at distance near $7 \mathrm{~km}$ in the southeast direction from the borders).

\section{Analysis and results discussion}

The main objective of the calculation of dispersion of pollutants is to define the settlement concentration of pollutants in a ground layer of the atmosphere and the influence of emissions of enterprise on the atmospheric air pollution, mainly near the housing estate, the results are included in the Table 2.

Table 2. The ground concentration of the pollutants created by emission from the operation sources.

\begin{tabular}{|c|c|c|c|c|c|c|}
\hline \multirow[b]{2}{*}{ Code } & \multirow[b]{2}{*}{ Substance } & \multirow[b]{2}{*}{$\begin{array}{c}\text { Threshold } \\
\text { limit value, } \\
\mathbf{g}^{\prime} \mathbf{m}^{3}\end{array}$} & \multicolumn{4}{|c|}{$\begin{array}{l}\text { Maximum concentration (maximum allowable } \\
\text { concentration share) in control points/without } \\
\text { a background }\end{array}$} \\
\hline & & & $\begin{array}{c}\text { Sanitary } \\
\text { protective } \\
\text { zone, } \\
\text { PT 1-4 }\end{array}$ & $\begin{array}{l}\text { Perspective } \\
\text { country } \\
\text { construction } \\
\text { PT } 5\end{array}$ & $\begin{array}{l}\text { Perspective } \\
\text { housing } \\
\text { construction, } \\
\text { PT } 6\end{array}$ & $\begin{array}{l}\text { Inhabited } \\
\text { zone, } \\
\text { PT } 7\end{array}$ \\
\hline 0301 & $\begin{array}{c}\text { Nitrogen } \\
\text { dioxide } \\
\text { (Nitrogen (IV) } \\
\text { oxide) } \\
\end{array}$ & 0.20000 & 0.26 & 0.25 & 0.21 & 0.21 \\
\hline 0303 & Ammonia & 0.20000 & 0.15 & 0.09 & 0.03 & 0.02 \\
\hline 0304 & $\begin{array}{l}\text { Nitrogen (II) } \\
\text { oxide (Nitrogen } \\
\text { oxide) }\end{array}$ & 0.40000 & 0.19 & 0.11 & 0.04 & 0.02 \\
\hline 0328 & Carbon (Soot) & 0.15000 & 0.12 & 0.07 & 0.02 & 0.01 \\
\hline 0616 & $\begin{array}{l}\text { Dimetilbenzol } \\
\text { (Xylol) }\end{array}$ & 0.20000 & 0.26 & 016 & 0.05 & 0.03 \\
\hline 0621 & $\begin{array}{c}\text { Methylbenzene } \\
\text { (Toluene) }\end{array}$ & 0.60000 & 0.14 & 0.08 & 0.03 & 0.02 \\
\hline 0627 & Ethyl benzene & 0.02000 & 0.28 & 0.17 & 0.06 & 0.03 \\
\hline 1325 & Formaldehyde & 0.03500 & 0.11 & 0.07 & 0.02 & 0.01 \\
\hline
\end{tabular}

The results of the calculation are presented in Table 2 for dispersion of pollutants shows that the maximum ground concentration in all control points will not exceed 0,1 threshold limit values an exception concentration of nitrogen makes dioxide (nitrogen (IV) oxide), ammonia, hydrogen sulfide, methane a Xylol, toluene, formaldehyde, ethyl benzene, and the sum of groups [8]. 
The result of calculation of dispersion of pollutants during the operation up to the end of operation (28.44 years) taking into account a waste sorting complex, shows that on all pollutants and sum of groups allocated in the atmosphere from sources, possible maximum ground concentration on border will not exceed criterion of 1 maximum permissible concentration. On the border of the next territories the quality of atmospheric air will not exceed 0.8 maximum of the allowable concentrations taking into account background concentration.

The ground concentration of the pollutants on the border of sanitary protection zone didn't exceed 1 maximum allowable concentration, and on the borders of other normalized territories didn't exceed 0.8 maximum allowable concentrations. However in the carried out researches, it wasn't taken in consideration the pollution to the atmosphere by the worn-out car tires because there were no unauthorized ignitions on the ground.

\section{Discussion}

Many years ago there was a strong need of creation of solid waste landfill which assumes burial of not utilized part of MSW after sorting. In 2015 the project of creation of the waste landfill on the Kola Peninsula was developed, but it doesn't include the enterprise for processing of waste. The landfill began to function since 2017. The morphological composition of MSW on the ground are: food waste, paper, tree, ferrous metal, non-ferrous metal, textiles, glass, skin, rubber, stones and polymeric materials.

Settlement capacity (geometrical volume) of the designed cards is $7901438 \mathrm{~m}^{3}$ (7111290 t) of waste with a density $0.9 \mathrm{~m}^{3} / \mathrm{t}$. The solid waste landfill is intended for waste disposal. The term of operation of the ground is 28,4 years then the territory of the closed cards is a subject to recultivation. The technological scheme of production provides reception, sorting, placement, consolidation and isolation of firm household and separate types of industrial wastes on the maps of the ground and the accompanying auxiliary operations. Murmansk region is one of the regions of the country with the biggest amount of the population with cars. It is possible to emphasize that it is an acute environmental and economic issue. Similar technologies for processing rubber in bread crumbs are widespread abroad, in Russia some enterprises are engaged in similar actions. Worn-out tires represent the most large-capacity production of the polymer waste. It is not a subject to natural decomposition, therefore processing and recycling of the tires have important economic and ecological value.

At the same time worn-out care tires are a source of valuable secondary raw materials: rubber (rubber), soot (almost pure carbon), metal and synthetic cord. 90\% of all rubber waste are in tires and represent a huge reserve of raw materials [9] The great value gets effective use of secondary raw materials. Tires represent valuable polymeric raw materials: $1 \mathrm{t}$ of tires contains about $700 \mathrm{~kg}$ of rubber which can be reused [10]. We offer to purchase the line for crushing and recycling of worn-out car tires. This equipment is called LPSh-300, the price of this device in the Russian Federation is about 1250000 rub. The technological line allows to process worn-out tires, including with a metal cord. The technology is based on the phenomenon of "pseudo-liquefaction" of rubber with high pressures and its expirations through openings in the special camera. More than $90 \%$ of the metal which is contained in the tire is removed at the first stages of processing, and rubber mix comes to further processing: crushing and separation.

The main advantages of technology are: small specific power consumption (needs to $0.54 \mathrm{kWh}$ for $1 \mathrm{~kg}$ of initial raw materials); and full ecological safety (rubber powders have high adsorptive ability and chemical activity), the crumb have big specific surface and after devulcanization it has close properties to the initial rubbers and maximum of commodity 
rubber powder. The industrial line represents the mini-plant which allows to carry out processing of automobile and cargo of auto tires with a metal cord and without it, the diameter is up to $1300 \mathrm{~mm}$ and the profile is up to $400 \mathrm{~mm}$ wide and also has a various rubber materials (riding cameras, waste of shoe factories and RTI plants) [11].

The technological line allows to receive a rubber crumb of two fractions: $50 \%$ is $0.1-1 \mathrm{~mm}$ (where the half of it is $0.1-0.5 \mathrm{~mm}$ ) and $50 \%$ has $1.1-3 \mathrm{~mm}$. Processing of tires by the equipment LPSh-300 is based on mechanical effect that excludes the necessity to apply difficult chemical reactions. At the end it allows to receive a clean ready-made product, without release of harmful substances and gases.

Processing of worn-out tires by mechanical methods allow to receive a rubber crumb. In principle, it provides sufficient economy of raw materials, and it is possible to use products of utilization in rubber mixes. Rubber powders - have high adsorptive ability and chemical activity, possess a big specific surface and after devulcanization they are similar to initial rubbers.

It defines spheres of their further application: as initial raw materials for receiving rubber (regenerating), for preparation of rubber-bituminous mastics and as active filler in paving; as initial raw materials for receiving various rubber product; as filler at production of composite materials on the basis of thermos layers; for plugging of wells when drilling; as the occluding material for collecting oil products from a surface of the water; as active filler in rubber mixes.

Textile cord: as initial raw materials for production of heat and sound insulating plates; for plugging of wells when drilling; as the reinforcing filler at production of composite elastomeric materials.

Metal cord: as initial raw materials for receiving irresponsible brands of steel; as the reinforcing filler at production of building and road constructions. Devulkanizied rubber: for production of rubber products (with introduction of the vulcanizing group); for preparation of bituminous and rubber mastics; for production of waterproofing and roofing materials; as active filler in rubber mixes at production of auto tires.

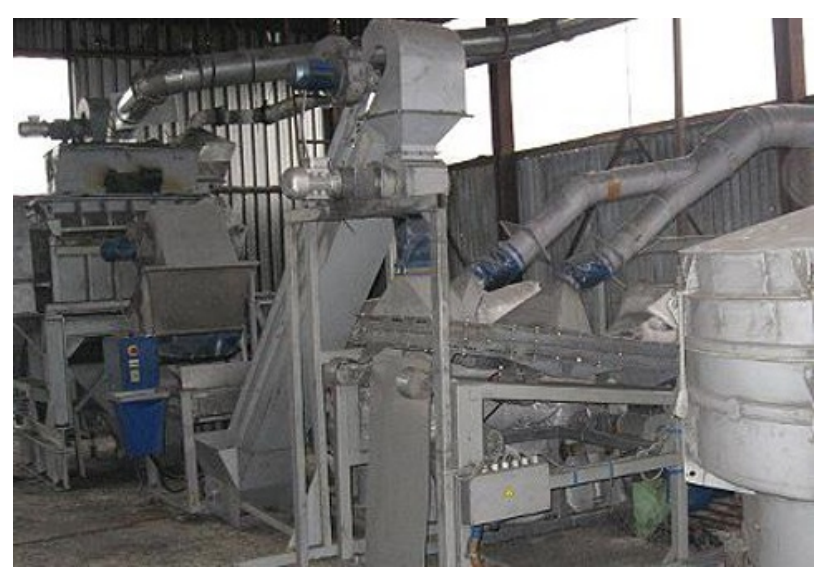

Fig. 1. The equipment for processing of tires LPSh-300.

The technological process of processing of tires is described as follows [12, 13]:

1. Sorting of tires according to a standard size. Sorting of tires takes into account the mass of a tire and diameter of an onboard ring, removal of visible mineral and metal inclusions. 
2. Separation of an on board ring. The tire is installed in the machine for removal of an onboard ring where the separation of an onboard ring from the tire is made.

3. Cutting of strips. The tire with a remote onboard ring is placed in the machine for cutting of strips. On a spiral the tire is cut on tapes $3-5 \mathrm{~cm}$ wide.

4. Cutting of preparations (chips).Strips from tires place in the machine for cutting of preparations (chips) then the received preparations are delivered on the tape conveyor.

Table 3. The general technical characteristics of the equipment for processing of tires LPSh-300 [11].

\begin{tabular}{|c|c|}
\hline \multicolumn{2}{|c|}{ Technical characteristics of the equipment for processing of tires } \\
\hline Productivity (the entrance volume of raw materials for processing), $\mathrm{kg} / \mathrm{h}$ & to 500 \\
\hline The general exit of a clean product, & to $300 \mathrm{~kg} / \mathrm{h}$ \\
\hline Exit of a textile cord, & to $36 \mathrm{~kg} / \mathrm{h}$ \\
\hline Exit of a metal cord, & to $84 \mathrm{~kg} / \mathrm{h}$ \\
\hline The maximum internal diameter of the processed tires, & $1500 \mathrm{~mm}$ \\
\hline Power, & from $100 \mathrm{~kW}$ \\
\hline Water consumption for cooling of rollers, & $10-15 \mathrm{l} / \mathrm{h}$ \\
\hline The number of the working personnel, & 8-9 people \\
\hline The required room apart from a warehouse, & $200 \mathrm{~m}^{2}$ \\
\hline \multicolumn{2}{|l|}{ Technical characteristics of machines } \\
\hline \multicolumn{2}{|l|}{ The machine for removal of an onboard ring } \\
\hline Power, & $4 \mathrm{~kW}$ \\
\hline Internal diameter of the tire, & Up to $1200 \mathrm{~mm}$ \\
\hline Productivity, & $25 \mathrm{piece} / \mathrm{h}$ \\
\hline Dimensions, & $1100 \times 900 \times 1700 \mathrm{~mm}$ \\
\hline Weight, & $500 \mathrm{~kg}$ \\
\hline \multicolumn{2}{|l|}{ The machine providing cutting of strips from the tire } \\
\hline Power, & $5.5 \mathrm{~kW}$ \\
\hline Internal diameter of the tire, & Up to $1200 \mathrm{~mm}$ \\
\hline Productivity, & $20 \mathrm{piece} / \mathrm{h}$ \\
\hline Tape width at the exit, & $35-55 \mathrm{~mm}$ \\
\hline Dimensions, & $1280 \times 870 \times 1550 \mathrm{~mm}$ \\
\hline Weight, & $880 \mathrm{~kg}$ \\
\hline \multicolumn{2}{|c|}{ The machine for separation of a metal cord from rubber of an onboard ring of the tire } \\
\hline Power, & $10 \mathrm{~kW}$ \\
\hline Dimensions, & $1540 \times 1160 \times 1200 \mathrm{~mm}$ \\
\hline Weight, & $1370 \mathrm{~kg}$ \\
\hline \multicolumn{2}{|l|}{ The grinder, for receiving a rubber crumb (rollers) } \\
\hline Power, & $70 \mathrm{~kW}$ \\
\hline Size of rolls, & $450 \times 760 \mathrm{~mm}$ \\
\hline Fraction & $1: 1,38$ \\
\hline Dimensions, & $4770 \times 1846 \times 1835 \mathrm{~mm}$ \\
\hline Weight, & $4000 \mathrm{~kg}$ \\
\hline \multicolumn{2}{|c|}{$\begin{array}{c}\text { An air separator - a pneumoseparation complex for separation of a textile cord from a rubber } \\
\text { crumb and dust }\end{array}$} \\
\hline $\begin{array}{ll}\text { Power, } \\
\end{array}$ & $5.5 \mathrm{~kW}$ \\
\hline Productivity, & $300-500 \mathrm{~kg} / \mathrm{h}$ \\
\hline Dimensions, & $1500 \times 1500 \times 3400 \mathrm{~mm}$ \\
\hline Weight, & $2500 \mathrm{~kg}$ \\
\hline
\end{tabular}


5. Division into components. Chips are served in a gap of valets where raw materials pass a crushing stage. Crushing is carried out at high pressure in a compression zone at various speeds of rotation of rolls. Then the received mix passes to the tape conveyor.

6. Separation. By magnetic separator, vibration and influence of magnetic fields, the extraction of metal from the lump consisting of rubber, metal and textiles is carried out. It is necessary to divide the stayed together textiles and rubber further. By means of a ladle tarporter mix of rubber and textiles give to an air and separation complex where by means of magnetic traps the metal remains separate. The separation of a textile cord from rubber occurs at the expense of strong vortex streams, vibration and the system of filters.

7. Division into fractions. The cleaned rubber crumb by means of the conveyor passes to a vibrosieve. To divide it into 4 different fractions vibration and grids with the different size of cells are used. Each fraction is shipped to a certain container. The sub-standard rubber crumb (the rubber crumb which is not corresponding to different sizes) and a large textile cord comes back to the grinder by means of the tape conveyor. Remote onboard rings are crushed to a condition of a rubber crumb separately, in the machine for removal of a metal cord.

\section{Conclusion}

Dealing with household waste in a subarctic zone is an important process for recycling. Its implementation was caused by the objective need of elimination of unauthorized landfills in the territory of the Kola Peninsula and simplifying the waste collection with reduces impacts on the environment. It was found out that for environmental protection the operational processes should be admissible.

However with the increased MSW and also due to the requirements for improvements concerned the ecological issues and the aspiration to reduce use of natural resources, also to save raw materials on the Mezhdurechie ground of Murmansk region it is better to use processing lines of worn-out tires.

The offered primary actions, protect from negative impact of worn-out tires on the environment and prevent the emergencies.

The secondary processing actions has better influence on the environment, simultaneously they also reduces the costs of the end products. Secondary processing can be exposed for aluminum jars, plastics, glass waste, waste paper and worn-out tires.

Use of products of processing of worn-out car tires has important social value for further development of the ecoindustry and ensures ecological safety and municipal economy.

The publication was prepared with the support of the "RUDN University program 5-100".

\section{References}

1. M. El-Fadel, A. N. Findikakis, J. O. Leckie, J. Environ. Manage. 50, 1 (1997)

2. K. Piekarska, M. Zaciera, A. Czarny, E. Zaczyńska, Environment Protection Engineering 37, 85-98 (2011)

3. K. Piekarska, Environment Protection Engineering 35, 25-35 (2009)

4. K. Bryś, T. Bryś, M. A. Sayegh, H. Ojrzyńska, Energy and Buildings 165, 64-75 (2018) 
5. D. Czajczyńska, L. Anguilano, H. Ghazal, R. Krzyżyńska, A. J. Reynolds, N. Spencer, H. Jouhara, Thermal Science and Engineering Progress 3, 171-197 (2017)

6. The report on a state and on environmental protection of Murmansk region in 2013 [Electronic resource]. Access mode free. http://new.govmurman. ru/region/environmentstate/2013.pdf/,- Title from the screen. - Russian language.

7. Temporary recommendations about calculation of emissions of harmful substances in the atmosphere in result of combustion on solid waste landfills and the size of the made claim for pollution of atmospheric air (Ministry of Natural Resources and Environmental Protection of the Russian Federation, 02.11.92)

8. Hygienic requirements to the device and the maintenance of grounds for municipal solid waste, Health regulations 2.1.7.1038-01

9. V. S. Demyanova, V. G. Kamburg, R. A. Dyarkin, East European Magazine of Advanced Technologies 2, 10, 50-52 (2012)

10. R. A. Dyarkin, V. S. Demyanova, Const. and arkhit. 32, 51, 200-205 (2013)

11. Equipment for processing of tires. [Electronic resource]. Access mode free http://www.uas.ru/compoundrecasttire.html

12. Equipment for processing of tires. [Electronic resource]. Access mode free http://www.bmpa.ru/oborudovanie-dlya-pererabotki-avtomobilnyh-shin-lpsh-300

13. M. C. Bignozzi, F. Sandrolini, Cement and Concrete Res. 36, 735 (2006) 